\title{
Active antifungal substances from natural sources
}

\author{
Maria José Abad, María Ansuategui, and Paulina Bermejo* \\ Department of Pharmacology, Faculty of Pharmacy, University Complutense, Avda. \\ Complutense s/n, 28040, Madrid, Spain \\ E-mail:naber@farm.ucm.es
}

Dedicated to Professor Atta-ur-Rahman on the Occasion of his $65^{\text {th }}$ Birthday

\begin{abstract}
The spread of multidrug-resistant strains of fungus and the reduced number of drugs available, makes it necessary to discover new classes of antifungals and compounds that inhibit these resistant mechanisms. This has led to a search for therapeutic alternatives, particularly among medicinal plants and compounds isolated from them used for their empirically antifungal properties. In these natural sources, a series of molecules with antifungal activity against different strains of fungus have been found, which are of great importance to humans and plants. In this article, we review the main sources of molecules with antimycotic activity obtained from the natural environment.
\end{abstract}

Keywords: Fungus, antifungals, medicinal plants

\section{Contents}

Introduction

1. Crude extracts

2. Essential oils

3. Terpenoids

4. Saponins

5. Phenolic compounds

6. Alkaloids

7. Peptides and proteins 


\section{Introduction}

In the past few decades, a worldwide increase in the incidence of fungal infections has been observed as well as a rise in the resistance of some species of fungus to different fungicidals used in medicinal practice. Fungi are one of the most neglected pathogens, as demonstrated by the fact that the amphotericin B, a polyene antibiotic discovered as long ago as 1956, is still used as a "gold standard" for antifungal therapy. The last two decades have witnessed a dramatic rise in the incidence of life threatening systemic fungal infections. The challenge has been to develop effective strategies for the treatment of candidiasis and other fungal diseases, considering the increase in opportunistic fungal infections in human immunodeficiency virus-positive patients and in others who are immunocompromised due to cancer chemotherapy and the indiscriminate use of antibiotics. The majority of clinically used antifungals have various drawbacks in terms of toxicity, efficacy and cost, and their frequent use has led to the emergence of resistant strains. Additionally, in recent years public pressure to reduce the use of synthetic fungicides in agriculture has increased. Concerns have been raised about both the environmental impact and the potential health risk related to the use of these compounds.

Hence, there is a great demand for novel antifungals belonging to a wide range of structural classes, selectively acting on new targets with fewer side effects. One approach might be the testing of plants traditionally used for their antifungal activities as potential sources for drug development. Medicinal plants are not only important to the millions of people for whom traditional medicine is the only opportunity for health care and to those who use plants for various purposes in their daily lives, but also as a source of new pharmaceuticals. Natural products, either as pure compounds or as standardised plant extracts, provide unlimited opportunities for new drug leads because of the matchedless availability of chemical diversity. This review aims to examine the recent efforts (1995 to date) towards discovering novel antifungal drugs of natural origin. The information has been organised into easily accessible and comparable sections, with reference to the crude extracts or isolated constituents studied.

\section{Crude extracts}

A review of the literature on the evaluation of medicinal plant extracts shows that many studies into their antifungal activities have been carried out in recent years. Various research group have initiated antifungal screening programmes for plants used all over the world as anti-infectious agents in traditional medicine.

Nineteen plant species from fourteen families used in traditional North American Indian medicine were tested for their fungicidal (Cladosporium cucumerinum and Candida albicans) activity. ${ }^{1}$ Of the species investigated, nine were active against Cladosporium cucumerinum and nine against Candida albicans. A programme was designed for the pharmacological screening of 
species used by the Mayan people in the highlands of Chiapas in southern Mexico to treat gastrointestinal and respiratory diseases. ${ }^{2}$ It demonstrated that $63 \%$ of the botanical species showed antifungal properties against Candida albicans.

Verastegui et l. $^{3}$ investigated the antifungal activity of several widely distributed plants in the vegetation of northern Mexico and the southern U.S.A. The plants were evaluated on the growth of yeasts and moulds: Candida albicans, Candida krusei, Candida rugosa, Cryptococcus neoformans, Cryptococcus laurentis, Cryptococcus albidus, Microsporum canis, Microsporum gypseum, Trichophyton tonsurans, Epidermophyton flocosum and Sporotrix schenckii. The extracts analysed showed good antifungal activity against more than one organism.

Another screening for antifungal agents was done on medicinal and fruit bearing plants used against skin diseases by the Brazilian population. ${ }^{4}$ The results, evaluated by the diameter of the inhibition zone of fungal growth, indicate that six plant species, among the sixteen investigated, showed significant activity against three fungi: Candida albicans, Trichophyton rubrum and Cryptococcus neoformans. Ethanol extracts from the leaves and/or roots of thirty five medicinal plants commonly used in Brazil were also screened for anti-Candida albicans activity. ${ }^{5}$ Extracts from thirteen plants showed activity.

Methanol extracts from eleven traditionally-used Argentine medicinal plants were assayed in vitro for antifungal activity against yeasts, hialohypomycetes as well as dermatophytes with the microbroth dilution method. ${ }^{6}$ Of these, the most pronounced effect was presented by Eupatorium bunifolium H.B.K. (Asteraceae) and Terminalia triflora (Griseb.) Lillo (Combretaceae).

As part of a European screening aimed at the selection of novel antimycotic compounds of vegetable origin, leaf extracts of Camelia sinensis L. (Theaceae), Cupressus sempervivens L. (Cupressaceae) and Pistacia lentiscus L. (Anacardiaceae), and the seed extract of Glycine soja Sieb. et Zucc. (Papilonaceae) were tested against yeast and yeast-like species implicated in human mycoses. ${ }^{7}$ Only extracts of $C$. sinensis exhibited widespread activity.

In recent years, there has also been a large number of antifungal screening programmes of medicinal plants used in the traditional medicine of Eastern Europe and Africa. Tadeg et al. ${ }^{8}$ investigated the antifungal activities of some selected traditional Ethiopian medicinal plants used in the treatment of skin disorders. Hydroalcohol extracts of Acokanthera schimperi (D.C.) Benth. et Hook. (Apocynaceae), Calpurna aurea L. (Leguminoseae), Kalanchoe petitiana (Engl.) Cufod. (Crassulaceae), Lippia adonensis Hochst. (Verbenaceae), Malva parviflora L. (Malvaceae), Olinia rochetiana L. (Oliniaceae), Phytolacca dodecandra L'Herit (Phytolaccaceae) and Verbascum sinaiticum Bentham (Scrophulariaceae) were screened for antifungal activity against different strains of fungi which are known to cause different types of skin infections. Of all the plants tested, L. adoensis and O. rochetiana were found to be the most active species against fungal strains.

Seventy seven crude extracts from leaves and stem barks of fifteen Gabonese plants used in traditional medicine were evaluated for their antifungal activities. ${ }^{9}$ The methanol extract of Polyalthia suaveolens Engler \& Diels (Polygonaceae) displayed good antifungal activity on all 
the strains tested with $\mathrm{IC}_{50}$ values (inhibitory concentration required for $50 \%$ inhibition) of 1 $\mathrm{mg} / \mathrm{ml}$. During interviews with the Pare people from north-eastern Tanzania, twenty nine plants used for medicinal purposes as well as fourty-one plants used for non-medicinal purposes were screened for antifungal activity. ${ }^{10}$ All plants showed activity against several test organisms.

Zaidi and Crow ${ }^{11}$ reported the antifungal activity of the following four important medicinal plants from Balochistan, Pakistan: Grewia erythraea Schwein f. (Tiliaceae), Hymenocrater sessilifolius Fisch. (Lamiaceae), Vincetoxicum stocksii Ali \& Khatoon (Asclepidaceae) and Zygophyllum fabago L. (Zygophyllaceae). The extracts of Z. fabago and $V$. stocksii showed good activity against Candida albicans. In an antifungal screening programme, thirty six extracts derived from ten plant species used by traditional Thai healers were assayed for their antifungal activity against clinical isolates of Candida albicans, Cryptococcus neoformans and Microsporum gypseum. ${ }^{12}$ The chloroform extract of Alpinia galanga (L.) Willd. (Zingiberaceae) and Boesenbergia pandurata (Robx.) Schltr. (Zingiberaceae) had pronounced antifungal activity against Cryptococcus neoformans and Microsporum gypseum, but exhibited weak activity against Candida albicans. Both plants are excellent candidates for the development of a remedy for opportunistic fungal infections in acquired immunodeficiency syndrome patients. Examples of other antifungal crude extracts of traditional medicinal plants also included those of plants used against venereal diseases in South Africa, ${ }^{13}$ and some medicinal plants from the Soqotra island in Yemen. ${ }^{14}$

Besides antifungal screening programmes, a review of the literature on the pharmacological evaluation of plant extracts shows that many studies into their antifungal activity have been carried out in recent years. These reports concern mainly the Asteraceae and Liliaceae families.

Members of the genus Echinops in the Asteraceae family are widely used in Ethiopian herbal medicine for the treatment of various diseases and illnesses such as migraine, diarrhoea, different forms of infections, intestinal worm infestation and haemorrhoids. Hydroalcohol extracts of the root, flower head, leaf and stem of Echinops ellenbeckii O. Hoffm. and Echinops longisetus A. Rich were investigated for their antifungal activity. ${ }^{15}$ The flower extract of $E$. ellenbeckii showed strong inhibitory activity against Candida albicans.

Plants from the genus Pterocaulon (Asteraceae), known as quitoco, are used to treat problems popularly diagnosed as mycoses, which may have a fungic etiology. In order to validate this traditional practice, the crude methanol extracts from the aerial parts of three species of Pterocaulon, Pterocaulon alopecuroides (Lam.) D.C., Pterocaulon balansae Chodat. and Pterocaulon polystachyum D.C., grown in southern Brazil were analysed for the in vitro antifungal activity against a panel of standardised and clinical opportunistic pathogenic yeasts and filamentous fungi, including dermatophytes. ${ }^{16}$ The crude methanol extract of $P$. polystachyum was the most active.

Extracts from roots of the common vegetable Cichorium intybus L. (Asteraceae), highly appreciated for its bitter taste, were studied to investigate their possible biological activity on fungi from a variety of ecological environments. ${ }^{17}$ The extracts were ineffective on geophilic 
species and on tested phytopathogens, with the exception of Pythium ultimum, whereas they inhibited the growth of zoophilic and anthropophilic dermatophytes, in particular Trichophyton tonsurans var. sulfureum.

Loizzo et $a .^{18}$ investigated the antifungal activity of methanol, ethyl acetate, dichloromethane, $n$-hexane, $n$-butanol and chloroform extracts of Senecio inaequidens D.C. and Senecio vulgaris L. (Asteraceae). The hexane extract of $S$. vulgaris showed significant activity against Trichophyton tonsurans ( $\mathrm{IC}_{50}$ of $0.031 \mathrm{mg} / \mathrm{ml}$ ). Examples of other antifungal crude extracts from the Asteraceae family also included Cynara scolymus L. extracts, ${ }^{19}$ the dichloromethane extract of the aerial part of Blumea gariepina D.C. which was shown to be active against the phytopathogenic fungus Cladosporium cucumerinum, ${ }^{20}$ and aqueous and petroleum ether extracts of Spilanthes calva D.C. which were active towards Fusarium oxysporum and Trichophyton mentagrophytes. ${ }^{21}$

In the Liliaceae family, reports on the antifungal activity concern mainly the Allium genus. By using an agar dilution assay, the antifungal activity of aqueous extracts prepared from Allium cepa L. (onion) and Allium sativum L. (garlic) were evaluated against Malassezia furfur, Candida albicans as well as several strains of various dermatophyte species. ${ }^{22}$ The results indicate that onion and garlic might be promising sources of drugs for the treatment of fungalassociated diseases from the important pathogenic genera Candida, Malassezia and the dermatophytes. The antifungal activity of onion and garlic was also investigated on two important dermatophytes, Trichophyton rubrum and Trichophyton mentagrophytes. ${ }^{23,24}$ From another Allium species, Allium ascalonicum O. Fedtsch, Amin and Kapadnis ${ }^{25}$ investigated the antifungal activity against twenty three strains of fungi. Among them, Aureobasidium pullulans and Microsporum gypseum were the most sensitive ( $\mathrm{IC}_{50}$ of $0.15 \mathrm{mg} / \mathrm{ml}$ ).

Other antifungal medicinal plants belong to the Leguminoseae, Rutaceae, Myrtaceae and Lamiaceae families. The effect of heartwood extracts from two Leguminoseae species, Acacia mangium Willd and Acacia auriculiformis A. Cunn., was examined on the growth of woodrotting fungi in in vitro assays. ${ }^{26}$ A. auriculiformis heartwood extracts had higher antifungal activity that $A$. mangium. The extracts of leaf, root, stem and the callus obtained from another Leguminoseae species, Pseudarthria viscida (L.) Wight \& Arn., showed significant inhibitory activity against some fungal pathogens causing major diseases in crop plants and stored food grains. $^{27}$

Antifungal activity of ethanol extracts of grapefruit, Citrus paradisis Macf. (Rutaceae) seed and pulp was examined against ten yeast strains. ${ }^{28}$ Yeasts were sensitive to extract concentrations ranging from 4.13 to $16.50 \%$. Leaf, fruit, stem, bark and root of another Rutaceae species, Zanthoxylum americanum Mill., were investigated for antifungal activity with eleven strains of fungi representing diverse opportunistic and systemic pathogens, including Candida albicans, Cryptococcus neoformans and Aspergillus fumigatus. ${ }^{29}$ All extracts demonstrated a broad spectrum of antifungal activity and inhibited at least eight fungal species in a disk diffusion assay. The results provide a pharmacological basis for the very widespread use of this 
plant in the indigenous North American ethnomedical tradition for conditions that may be related to fungal infections.

Reports on the antifungal activity of medicinal species belonging to the Myrtaceae family include the herbal food clove Syzygium aromaticum L. (Merr. \& Perry), ${ }^{30}$ and extracts of Eucalyptus globulus Labill., Eucalyptus maculata Hook. and Eucalyptus viminalis Labill. which significantly inhibited the growth of the fungus Trichophyton mentagrophytes. ${ }^{31}$

Ocimum gratissimum L. (Lamiaceae), a plant known as alfavaca, has been reported as having in vitro activity against the dermatophytes Microsporum canis, Microsporum gypseum, Trichophyton rubrum and Trichophyton mentagrophytes. ${ }^{32}$ Trichophyton rubrum, the most common etiological agent of dermatophytosis in Goiania, state of Goias, Brazil, was the most susceptible dermatophyte. The plant was also active towards twenty five isolates of Cryptococcus neoformans, the etiological fungus responsible for cryptococcal infections. ${ }^{33}$ Another Lamiaceae species, Satureja khuzistanica Jamzad was also active against Candida albicans. $^{34}$

Other antifungal medicinal plants belong to the Combretaceae, Zingiberaceae, Amaryllidaceae and Euphorbiaceae families. Masoko et al. ${ }^{35}$ investigated the antifungal activities of six South African Terminalia species (Combretaceae), Terminalia prunioides M.A. Lawson, Terminalia brachystemma Welw. ex Hiern, Terminalia sericea Burch ex D.C., Terminalia gazensis Bak. f., Terminalia mollis Laws and Terminalia sambesiaca Engl. \& Diels. against five fungal animal pathogens (Candida albicans, Cryptococcus neoformans, Aspergillus fumigatus, Microsporus canis and Sporothrix schenkii). T. sericea extracts were the most active against nearly all the microorganisms tested. Five species of Combretaceae growing in Togo were also investigated for their antifungal activity against twenty pathogenic fungi in order to confirm the traditional therapeutic properties of these plants. ${ }^{36}$ The hydroethanol extracts of Terminalia glaucescens Planch. ex Benth. (L.) and Anogeissus leiocarpus (D.C.) Guill. et Perr. (L.) appeared to be the most active, with $\mathrm{IC}_{50}$ values ranging from 0.25 to $4 \mathrm{mg} / \mathrm{ml}$.

In the Zingiberaceae family, the ethanol extract of Curcuma longa L. and A. galanga were also found to possess good antifungal activities against Trichophyton longifusus. ${ }^{37}$ Other Curcuma species from the Zingiberaceae family, Curcuma zedoaria Rosc. and Curcuma malabarica Vel., also presented antifungal activity which supports the use of their tubers in traditional medicine for the treatment of bacterial and fungal infections. ${ }^{38}$

One member of the Amaryllidaceae family, Polianthes tuberosa L., was evaluated against the mycelial growth of Colletotrichum gloeosporioides on potato-dextrose-agar medium. ${ }^{39}$ Examples of other antifungal crude extracts from the Amaryllidaceae family also included Sternbergia sicula Tineo ex Guss. and Sternbergia lutea (L.) Ker-Gawl. ex Spreng. ${ }^{40}$

Based on an ethnobotanical approach, the dragon's blood collected from Croton urucurana Baill. (Euphorbiaceae) bark was tested for antifungal activity against five dermatophytes by the paper disk diffusion method. ${ }^{41}$ The test dermatophytes were Trichophyton tonsurans, Trichophyton mentagrophytes, Trichophyton rubrum, Microsporum canis and Epidermophyton floccossum. The dragon's blood $(0.175-3 \mathrm{mg} / \mathrm{ml})$ exhibited an inhibition zone range of 7.6-26.9 
$\mathrm{mm}$ against all the tested fungi, with $\mathrm{IC}_{50}$ of $1.25-2.5 \mathrm{mg} / \mathrm{ml}$. Another member of the Euphorbiaceae family, Phyllanthus amarus Schumach \& Thonn., was also tested against the dermatophytic fungus Microsporum gypseum. ${ }^{42}$ The chloroform extract of the aerial part of the plant showed a significant inhibitory effect against this dermatophytic fungus.

Reports on the antifungal activity of the extracts of several medicinal species belonging to other botanical families have also been found in the literature. Some of these plants have been reported to be used in folk medicine as anti-infectious agents.

Pycnogenol, a standardised extract of Pinus pinaster Ait. (Pinaceae), was tested for its antifungal activity towards twenty three different yeast and fungi microorganisms. ${ }^{43}$ Pycnogenol inhibited the growth of all the tested microorganisms in minimum concentrations ranging from 20 to $250 \mu \mathrm{g} / \mathrm{ml}$. These results conform with clinical oral healthcare studies describing the prevention of plaque formation and the clearance of candidiasis by pycnogenol. Zizyphus lotus (L.) Desf. (Rhamnaceae) is one of the traditional drugs commonly used in folk medicine in Morocco. Extracts obtained from the successive exhaustion in petroleum ether, chloroform, ethyl acetate and methanol were found active in vitro against nine pathogenic fungi. ${ }^{44}$ The chloroform extract in particular appeared to be the most interesting in antifungal tests at lower concentrations.

De Campos et $a l .{ }^{45}$ investigated the crude methanol extract and some fractions (hexane, dichloromethane and ethyl acetate) from Piper solmsianum C. D.C. var. solmsianum (Piperaceae) for possible antifungal activity against twelve pathogenic fungi. The experiments showed that the crude extract exhibited antifungal action against all the dermatophytes tested, with $\mathrm{IC}_{50}$ values of between 20 to $60 \mu \mathrm{g} / \mathrm{ml}$. Similar activity was also verified for the hexane, dichloromethane and ethyl acetate fractions. The antifungal activity of Nigella sativa L. (Ranunculaceae) seed was tested against eight species of dermatophytes: four species of Trichophyton rubrum and one each of Trichophyton interdigitale, Trichophyton mentagrophytes, Epidermophyton floccosum and Microsporum canis. ${ }^{46}$ These results denote the potentiality of $N$. sativa as a source for antidermatophyte drugs, and support its use in folk medicine for the treatment of fungal skin infections.

The antifungal activity of a crude extract from Yucca gloriosa L. (Agavaceae) flowers, named alexin, was investigated in vitro against a panel of human pathogenic fungi and yeasts, as well as dermatophytes and filamentous species. ${ }^{47}$ Alexin had a broad spectrum of antifungal activity for all the tested yeast strains, except for Candida lusitaniae and Candida kefyr. It was also active against several clinical Candida isolates known to be resistant to the usual antifungal agents. One member of the Nyctaginaceae family, Boerhavia diffusa L., was active against the dermatophytic species of Microsporum gypseum, Microsporum fulvum and Microsporum canis. $^{48,49}$

Crude methanol extracts and fractions from the aerial parts of seven species of Hypericum (Gutiferaceae) growing in southern Brazil were analysed for their in vitro antifungal activity against a panel of standardised and clinical opportunistic pathogenic yeasts and filamentous fungi, including dermatophytes. ${ }^{50}$ Chloroform and hexane extract of Hypericum ternum A. St.- 
Hill. showed the greatest activity among the extracts tested. Rojas et al. $^{51}$ investigated the antifungal activity of Gentianella nitida Griseb. (Gentianaceae). The most susceptible microorganisms were Candida albicans, Trichophyton mentagrophytes and Microsporum gypseum. The antifungal activity was concentrated in the $90 \%$ methanol and non-soluble fractions.

The $n$-butanol soluble part and four fractions of the aqueous ethanol extract of the leaves of Daniellia oliveri (Rolfe) Hutch \& Dalziel (Fabaceae) were active against the fungus Trichophyton rubrum, ${ }^{52}$ while the aqueous extract from the plant $P$. dodecandra (Phytolaccaceae) showed fungicidal activity against dermatophytes. ${ }^{53}$ The seeds of two Apiaceae species, Ligusticum hultenii Fernald and Lomatium californicum (Nutt.) Math. \& Const. were investigated for antifungal activity. ${ }^{54}$ Preliminary bioassays indicated that the methylene chloride extracts of the seeds of both species had antifungal activity against Colletotrichum fragariae.

Examples of other antifungal crude extracts from medicinal species also included Bauhinia racemosa L. (Caesalpiniceae) stem bark, ${ }^{55}$ the latex of gazyumaru (Ficus microcarpus L., Moraceae), ${ }^{56}$ Larrea divaricata Cav. (Zygophyllaceae) which presented fungitoxic activity against yeasts and fungi, ${ }^{57}$ and leaf extracts of Tapinanthus sessilifolius (P. Beauv) Van Tiegh. (Loranthaceae) which was active towards Candida albicans. ${ }^{58}$

\section{Essential oils}

The increasing resistance to antifungal compounds and the reduced number of available drugs led us to search for therapeutic alternatives among aromatic plants and their essential oils, used for their empirically antifungal properties. In recent years, these reports have involved mainly the Lamiaceae and Asteraceae families.

The antifungal effect on Candida albicans growth of the essential oils from several species of the Lamiaceae family, Satureja montana L., Lavandula angustifolia Mill., Lavandula hybrida Reverchon, Origanum vulgare L., Rosmarinus officinalis L. and six chemotypes of Thymus vulgaris L. were studied. ${ }^{59}$ The greatest efficiency was obtained with the essential oil from the $T$. vulgaris thymol chemotype ( $\mathrm{IC}_{50}$ of $\left.0.016 \mu \mathrm{g} / \mathrm{ml}\right)$. From two of these genera, Lavandula and Rosmarinus, extensive works on the antifungal activity of their essential oils have been reported.

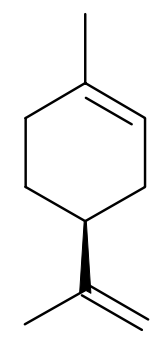

Figure 1. Structure of limonene 
The antifungal activity of the essential oil of L. angustifolia (lavender oil) and its main components, linalool and linalyl acetate, was investigated against fifty clinical isolates of Candida albicans (oropharyngeal and vaginal strains). ${ }^{60}$ Linalool was more effective than essential oil, although linalyl acetate was almost ineffective. Angioni et al. ${ }^{61}$ investigated the chemical composition and antifungal activity of the essential oil from the stems/leaves and flowers of another Lavandula species growing wild in southern Sardinia, Italy, Lavandula stoechas L. ssp. stoechas. The essential oils tested were effective on the inactivation of Rhizoctonia solani and Fusarium oxysporum, and less effective against Aspergillus flavus. Among the single components tested, fenchone, limonene (Figure 1) and myrtenol appeared to be the most effective on the inhibition of Rhizoctonia solani growth. The chemical composition of the essential oil of the Sardinian $R$. officinalis obtained by hydro-distillation was also studied. ${ }^{62}$ The major compounds in the essential oil were $\alpha$-pinene, borneol (Figure 2), camphene, camphor, verbenone and bornyl acetate. An inhibitory effect on fungal growth, especially toward Fusarium graminearum, was observed.

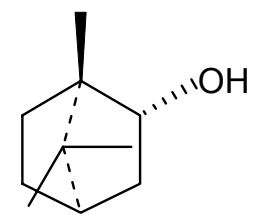

Figure 2. Structure of borneol

Other antifungal essential oils from the Lamiaceae family are those from species of the genera Ocimum, Nepeta and Thymbra. The in vitro antifungal activity of the essential oil of $O$. gratissimum was investigated in order to evaluate its efficacy against Candida albicans, Candida krusei, Candida parapsilosis and Candida tropicalis. ${ }^{63}$ These results demonstrated that the essential oil showed fungicidal activity against all of the Candida species studied. Analysis of the ultrastructure of the yeast cells revealed changes in the cell wall and in the morphology of some subcellular organelles. The essential oil from another species of the Ocimum genus, the wild Amazonian basil Ocimum micranthum Willd., showed a dose-dependent antifungal activity against pathogenic and food spoiling yeasts. ${ }^{64}$

The composition and antifungal activity of the essential oil of Nepeta crispa Willd. (Lamiaceae), an endemic species from Iran, was studied. ${ }^{65}$ The oil exhibited a noticeable antifungal activity against all the tested fungi. Twenty three compounds, accounting for $99.8 \%$ of the total oil, were identified. The main constituents were 1,8 -cineole and $4 \alpha, 7 \alpha-$ abetanepetalactone. The composition and the antifungal activity of the essential oil of Thymbra capitata (L.) Cav. (Lamiaceae) on Candida, Aspergillus and dermatophyte strains were also studied. ${ }^{66}$ The oil exhibited antifungal activity for all the strains tested, particularly for dermatophytes, with $\mathrm{IC}_{50}$ values ranging from 0.08 to $0.32 \mu \mathrm{g} / \mathrm{ml}$. All samples are of the 
carvacrol type, with a high content of carvacrol and its biogenetic precursors, $\gamma$-terpinene and $p$ cymene.

Reports on the antifungal activity and chemical composition of the essential oils from aromatic plants belonging to the Asteraceae family have also been found in the literature. The antifungal activity of the essential oil of flowerheads of garland chrysanthemum Chrysanthemum coronarium L. (Asteraceae) was evaluated against twelve agricultural pathogens. ${ }^{67}$ Flowerhead oil was active both in contact and headspace in vitro assays and produced hyphal growth inhibition, although there was less activity on faster growing fungi. The main compounds in the oil were camphor, $\alpha$ - and $\beta$-pinene and lyratyl acetate.

Kordali et $a l .{ }^{68}$ investigated the chemical composition and antifungal activity of the essential oils from three Turkish Artemisia species (Asteraceae): Artemisia absinthium L., Artemisia santonicum L. and Artemisia spicigera C. Koch. The results showed that all the oils had potent inhibitory effects over a very broad spectrum against all the fungi tested. Pure camphor and 1,8-cineole, which are the major components of the oils, were also tested for antifungal activity against the same fungal species. Compounds showed antifungal activity against some of the fungal species.

The composition of the leaf oils, obtained by hydro-distillation, of five endemic Psiadia species of the Asteraceae family from Mauritius, were also studied. ${ }^{69}$ In vitro antifungal assays, using the agar-well diffusion method, revealed that most of the oils were not very active against the tested microorganisms, except for that of Psiadia lithospermifolia Lam., which significantly inhibited the growth of Aspergillus ochraceus, Candida pseudotropicalis and Fusarium moniliforme. This activity has been attributed to the presence of $\delta$-elemene, farnesene, $\alpha$ curcumene, selina-4,7(11)-diene and $\beta$-bisabolene, some of which have established antifungal profiles.

The essential oil extracted by steam distillation from the capitula of Indian Tagetes patula L. (Asteraceae) was evaluated for its antifungal properties. ${ }^{70}$ The oil exerted good antifungal activity against two phytopathogenic fungi, Botrytis cinerea and Penicillium digitatum, providing complete growth inhibition at 10 and $1.25 \mu \mathrm{g} / \mathrm{ml}$, respectively. The contribution of the two main compounds, piperitone and piperitenone, to the antifungal efficacy was also evaluated, and structural modifications in mycelia were observed via electron microscopy, displaying considerable alterations in hyphal morphology and a multi-site action mechanism. Examples of other antifungal essential oils from the Asteraceae family also included the essential oil of Chrysactinia mexicana Grag, which completely inhibited Aspergillus flavus growth, ${ }^{71}$ and Helichrysum italicum (Roth) Don growing wild in Calabria and Sardinia, Italy, which was active against the phytopathogenic fungus Pythium ultimum. ${ }^{72}$

Other antifungal essential oils from medicinal plants belong to the Verbenaceae, Rutaceae, Lauraceae and Cupressaceae families. Some of these medicinal and aromatic plants have been reported to be anti-infectious agents.

Mexican oregano, Lippia berlandieri Shauer (Verbenaceae) grows wild in the desert zone of Mexico and is commonly added to regional foods. Portillo et al. ${ }^{73}$ initiated studies to evaluate 
the antifungal activity of Mexican oregano versus food-contaminant fungi. The oregano essential oil was inhibitory to all fungal strains tested, but there were differences in the extent of the effect. Although the antifungal effect of oregano is strongly established, there was a differential effect with the fungal strains studied. Another species from the genus Lippia, Lippia javanica (Burm. f.) Spreng, is widely distributed throughout South Africa, where it is used extensively in traditional herbal preparations. An infusion of the leaves is commonly used as a decongestant for colds and coughs. Recently, Viljoen et al. ${ }^{74}$ reported the antimicrobial activity of L. javanica leaf essential oil against some fungi. The essential oils of two members of the Verbenaceae family, Aloysia triphylla (Ort.) H.B.K. and Aloysia polystachya (Gris.) Mol., were also active towards Fusarium verticillioides. $^{75}$

In the Rutaceae family, the essential oil extracted from the epicarp of Citrus sinensis (L.) Osbeck exhibited absolute fungitoxicity against ten post-harvest pathogens. ${ }^{76}$ The chemical composition and antifungal activity of the essential oil of Haplophyllum tuberculatum (Forsskal) A. Juss (Rutaceae) was also analysed. ${ }^{77}$ The oil affected the mycelial growth of Curvularia lunata and Fusarium oxysporium in a dose-dependent manner, but had no effect on the germination of their spores. Thirty compounds, constituting about $99.7 \%$ of the total oil, were identified. The most abundant oil components were $\alpha$ - and $\beta$-phellandrene, limonene (Figure 1), $\beta$-ocimene, $\beta$-caryophyllene and myrcene.

The antifungal activity of the essential oils from several aromatic species from the Lauraceae family, Aniba rosaedora Ducke, Laurus nobilis L., Sassafras albidum (Nutt.) Nees and Cinnamomum zeylanicum Blume were investigated against seventeen micromycetes. ${ }^{78}$ Among the fungal species tested were food poisoning and food spoilage fungi, and plant and animal pathogens. Linalool was the main component in the essential oil of $A$. rosaedora, while 1,8-cineole was dominant in L. nobilis. Safrole was the major component in S. albidum essential oil, and the main component of the oil of $C$. zeylanicum was trans-cinnamaldehyde. The essential oil of $C$. zeylanicum showed the strongest antifungal activity. Another antifungal Cinnamomum species is Cinnamomum osmophloeum Kaneh, a hardwood species indigenous to Taiwan, which has significant antifungal activity against wood decay fungi. ${ }^{79}$

From the Cupressaceae family, Calocedrus formosana Florin is an endemic tree species in Taiwan. Its timber is recognised for its natural resistance to decay. Cheng et al. ${ }^{80}$ investigated the antifungal activity of its essential oil. Leaf oil constituents displayed activity against four fungi: Lenzites betulina, Pycnoporus coccineus, Trametes versicolor and Laetiporus sulphurous. Two compounds, $\alpha$-cadinol and muurolol, exhibited the strongest antifungal activity. The antifungal activity of the essential oil from another coniferous tree, Chamaecyparis obtusa (Siebold \& Zucc.) Siebold \& Zucc. ex Endl. was also reported. ${ }^{81}$ The oil had antifungal effects and the main component was bornyl acetate. Examples of other antifungal essential oils from the Cupressaceae family also included Juniperus comunis L. essential oil which was active against the dermatophyte Aspergillus and Candida strains. ${ }^{82}$

Reports on the antifungal activity of essential oils from aromatic medicinal plants belonging to other botanical families have also been found in the literature. In an attempt to 
develop stable and antifungal agents from natural products (daily food stuffs in particular), the activity of essential oils from Allium fistulosum L., A. sativum and A. cepa (Liliaceae) were investigated against three Trichophyton species responsible for severe mycoses in humans. ${ }^{83}$ Among the oils tested, A. sativum oil exhibited the strongest inhibition of growth of Trichophyton rubrum with an $\mathrm{IC}_{50}$ value of $61 \mu \mathrm{g} / \mathrm{ml}$, while the activities of $A$. cepa and $A$. fistulosum were relatively mild.

Singh et $a{ }^{84}{ }^{8 n v e s t i g a t e d ~ t h e ~ c h e m i c a l ~ c o n s t i t u e n t s ~ a n d ~ a n t i f u n g a l ~ e f f e c t s ~ o f ~ a j w a i n ~}$ essential oil, Trachyspermum ammi (L.) Sprague (Apiaceae). The oil exhibited a broad spectrum of fungitoxic behaviour against all tested fungi, such as Aspergillus niger, Fusarium moniliforme and Curvularia lunata, as absolute mycelial zone inhibition was obtained at a $6 \mu$ lose of the oil. Analysis of ajwain essential oil showed the presence of twenty six identified components, which account for $96.3 \%$ of the total amount. Thymol was found to be a major component along with $p$-cymene, $\gamma$-terpinene, $\beta$-pinene and terpinen-4-ol. The essential oils from different tissues of Japanese cedar, Cryptomeria japonica D. Don (Taxodiaceae) were active against four wood decay fungi and six tree pathogenic fungi, ${ }^{85}$ while essential oil isolated by hydro-distillation from the aerial parts of Chenopodium botrys L. (Chenopodiaceae) showed significant fungicidal activity. ${ }^{86}$

Examples of other antifungal essential oils from medicinal plants also included those from C. sinensis (Theaceae), ${ }^{87}$ Croton cajucara Benth (Euphorbiaceae) linalool-rich essential oil, ${ }^{88}$ the essential oil of Pelargonium graveolens L'Herit ex Aiton (Geraniaceae) which was active against Trichophyton spp., ${ }^{89}$ and the aerial parts of Bupleurum gibraltaricum Lamarck (Umbeliferae), which yielded an antifungal essential oil active towards Plasmopara halstedii in sunflower. ${ }^{90}$ The main compounds in this oil were sabinene, $\alpha$-pinene and 2,3,4-trimethylbenzaldehyde.

\section{Terpenoids}

A large number of studies have been done in recent years on the antifungal activity of terpenoids of natural origin. These reports concern mainly sesquiterpenes and sesquiterpene lactones. Some of these compounds were isolated by bioassay-guided fractionation, after previously detecting antifungal activity on the part of the plant. 


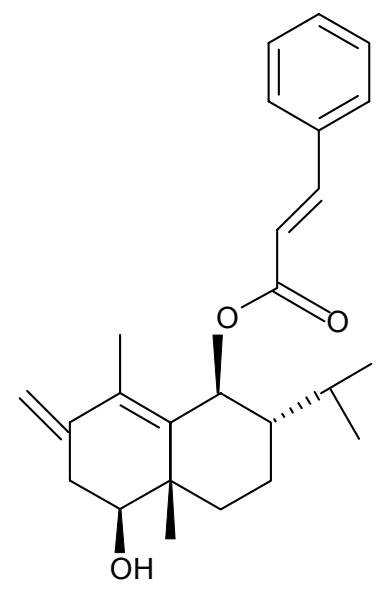

Figure 3. Structure of 6-cinnamoyloxy-1-hydroxyeudesm-4-en-3-one

Phytochemical and biological investigation of the roots of the wild carrot, Daucus carota L. ssp. carota (Apiaceae), afforded four sesquiterpene daucane esters. ${ }^{91}$ Based on an agar diffusion assay, compounds were screened and found to contain a range of low antifungal activity against Fusarium oxysporum and Aspergillus niger. This species also yielded the sesquiterpenes carotol, daucol and $\beta$-caryophyllene. ${ }^{92}$ Carotol, which was observed to be the main constituent of carrot seed, inhibited the radial growth of fungi by $65 \%$. The bioassayguided fractionation of the antifungal dichloromethane extract from the roots of Vernonanthura tweedieana (Baker) H. Rob. (Asteraceae), allowed the isolation of one active sesquiterpene, identified as 6-cinnamoyloxy-1-hydroxyeudesm-4-en-3-one (Figure 3). ${ }^{93}$ Trichophyton mentagrophytes was the most sensitive strain.

A dichloromethame and a methanol extract of the liverwort Bazzania trilobata (L.) S.F. Gray (Lepidoziaceae) showed antifungal activity against the phytopathogenic fungi Botrytis cinerea, Cladosporium cucumerinum, Phythophthora infestans, Pyricularia oryzae and Septoria tritici. From these extracts, Scher et $a .^{94}$ isolated six antifungal sesquiterpenes: 5- and 7hydroxycalamenene, drimenol (Figure 4), drimenal, viridiflorol, gymnomitrol and chloroisopiagiochin D. Polygodial, a sesquiterpene isolated from Polygonum punctatum Elliot. (Polygonaceae), was found to exhibit a fungicidal activity against a food spoilage yeast, Zygosaccharomyces bailii. ${ }^{95}$ The time-kill curve study showed that polygodial was fungicidal at any growth stage.

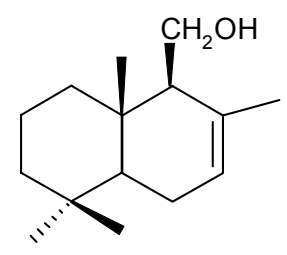

Figure 4. Structure of drimenol 
Examples of other antifungal sesquiterpenes from medicinal species also included those isolated from Juniperus thurifera L. (Cupressaceae) wood, ${ }^{96}$ and antifungal sesquiterpenes from the root exudates of Solanum abutiloides (Griseb.) Bitter \& Lillo (Solanaceae) which inhibited the spore germination of Fusarium oxysporum. ${ }^{97}$

Reports on antifungal sesquiterpene lactones from natural sources mainly concern those isolated from medicinal species of the Asteraceae family. In the search for new sources of sesquiterpene lactones, Barrero et al. ${ }^{98}$ investigated six Centaurea species: Centaurea bombycina Boiss ex D.C., Centaurea granatensis Boiss, Centaurea monticola Boiss, Centaurea incana Desf., Centaurea maroccana Ball. and Centaurea sulphurea Willd. The activity of the sesquiterpene lactones isolated from the Centaurea plants against the fungus Cunninghamella echinulata was evaluated. Of these, costunolide (Figure 5) and dehydrocostunolide showed noticeable $\mathrm{IC}_{50}$ values, whilst more polar lactones were inactive. These results suggest that a relatively low polarity is one of the molecular requirements for the antifungal activity of sesquiterpene lactones. From other Centaurea species, Centaurea thessala Hausskn. and Centaurea attica Nym., two new eudesmanolides, 4-epi-sonchucarpolide and their 8-(3hydroxy-4-acetoxy-2-methylene-butanoyloxy) derivative, and one new eudesmane derivative named atticin, were isolated. ${ }^{99}$ The in vitro antifungal activity of these sesquiterpene lactones was tested against nine fungal species using the micro-dilution method. All the compounds showed a considerable antifungal effect.

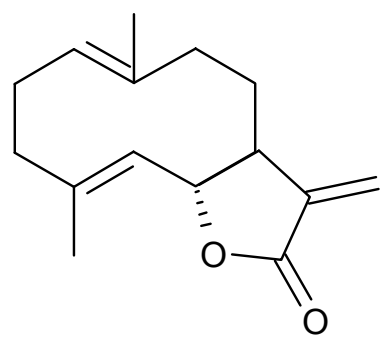

Figure 5. Structure of costunolide

Examples of other antifungal sesquiterpene lactones from the Asteraceae family also included those isolated from Ajania fruticulosa (Lebeb.) Poljak, ${ }^{100}$ and seven xanthanolides from Xanthium macrocarpum D.C. which were effective against Candida albicans, Candida glabrata and Aspergillus fumigatus. ${ }^{101}$

Besides sesquiterpenes and sesquiterpene lactones, studies into other antifungal terpenoids from medicinal species also included diterpenoids and triterpenoids. Some of these compounds were isolated by bioassay-guided fractionation after previously detecting antifungal activity on the part of the plant.

A fruit pulp extract of Detarium microcarpum Guill. et Perr. (Leguminoseae) showed inhibition of the growth of the plant pathogenic fungus Cladosporium cucumerinum. ${ }^{102}$ Fractionation of this extract led to the isolation of four new clerodane diterpenes which showed 
antifungal activity. The diterpenoids 16 $\alpha$-hydroxy-cleroda-3,13-(14)-Z-diene-15,16-olide and 16-oxo-cleroda-3,13-(14)-E-diene-15-oic acid (Figure 6) isolated from the hexane extract of the seeds of Polyalthia longifolia (Som.) Thw (Annonaceae) also demonstrated significant antifungal activity. ${ }^{103}$

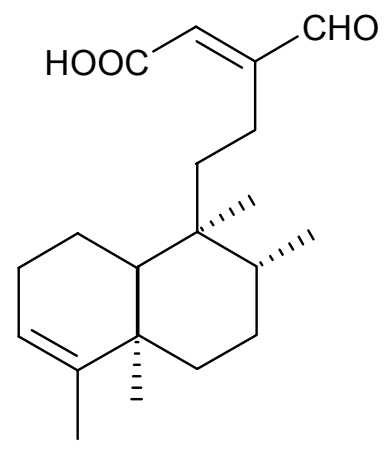

Figure 6. Structure of 16-oxo-cleroda-3,13-(14)-E-diene-15-oic acid

Bioassay-guided fractionation of the methanol and ethyl acetate extracts of two lianas from the genus Casimirella (Miers) RA Howard (Icacinaceae) collected in the Suriname rainforest, has led to the isolation of five new diterpenoids: humirianthone, 1-hydroxy-humirianthone, $15 R$ humirianthol, patagonol and patagonal. ${ }^{104}$ All the diterpenoids showed activity against phytopathogenic fungi. Examples of other antifungal diterpenoids from medicinal species also included oxygenated pimarane diterpenes from Kaempferia marginata Caney ex Roscoe (Zingiberaceae). ${ }^{105}$

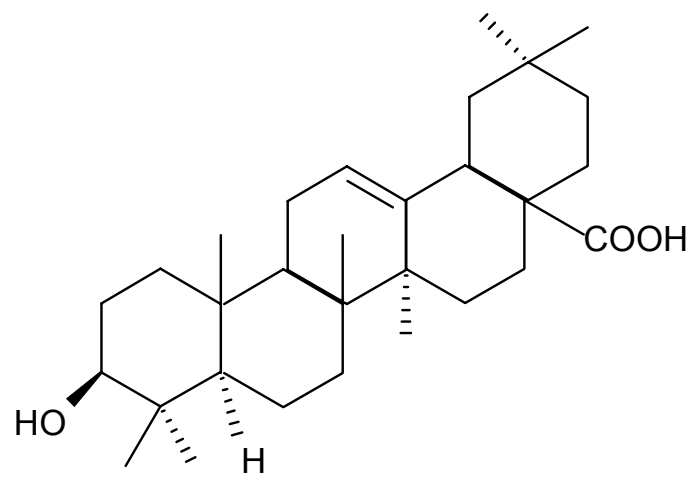

Figure 7. Structure of oleanolic acid

Chemical investigation of the diethyl ether extract of the stem bark of Khaya ivorensis A Chev (Meliaceae) afforded ten highly oxygenated triterpenes. ${ }^{106}$ These compounds were evaluated for their antifungal activity against the plant pathogenic fungus Botrytis cinerea. Methyl angolensate and 1,3,7-trideacetylkhivorin displayed the highest antifungal activity, with 
62.8 and $64 \%$ mycelial growth inhibition at $1000 \mathrm{mg} / 1$, respectively. Lythrum salicaria L. (Lytraceae) extracts showed activity against the phytopathogenic fungus Cladosporium cucumerinum. Becker et al. ${ }^{107}$ isolated the two antifungal triterpenoids, oleanolic acid (Figure 7) and ursolic acid.

The triterpenoids pristimerin and celastrol isolated from the roots of Celastrus hypoleucus (Oliv) Warb f. Argurtior Loes (Celastraceae) exhibited inhibitory effects against diverse phytopathogenic fungi such as Rhizoctonia solani and Glomerelia cinguiata. ${ }^{108}$ Examples of other triterpenes from medicinal plants also included a novel oleanane triterpenoid, triterpenetetrol (Figure 8), isolated from the chloroform extract of the aerial parts of Leontodon filii (Hochst. ex Seub.) Paiva et Orm (Asteraceae). ${ }^{109}$

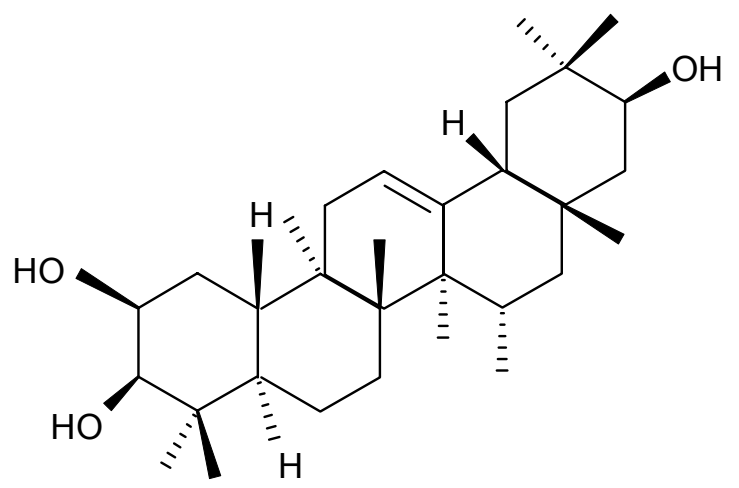

Figure 8. Structure of triterpenetetrol

\section{Saponins}

Compounds chemically related to the triterpenoid group, such as triterpene saponins, together with steroidal saponins, were also isolated as antifungal constituents from medicinal plants. These reports concern mainly members of the Solanaceae family.

CAY-1, a novel triterpene saponin from the Capsicum frutescens L. (Solanaceae) plant commercially known as cayenne pepper, was investigated to determine its in vitro antifungal activity. ${ }^{110}$ CAY-1 was active against sixteen different fungal strains, including Candida spp. and Aspergillus fumigatus, and was especially active against Cryptococcus neoformans. Importantly, CAY-1 appears to act by disrupting the membrane integrity of fungal cells.

A novel spirostanol saponin, together with three known saponins, were isolated from the leaves of Solanum hispidum Pers. (Solanaceae). ${ }^{111}$ All the isolated compounds showed antimycotic activity. The most active compound was $6 \alpha-O-[\beta-D$-xylopyranosyl- $(1 \rightarrow 3)-\beta-D$ -

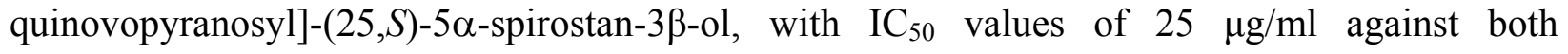
Trichophyton mentagrophytes and Trichophyton rubrum. From another Solanum species, Solanum chrysotrichum Schltdl., five new spirostan saponins were isolated using bioactivity- 
directed isolation procedures. ${ }^{112}$ These compounds showed antimycotic activity against Trichophyton mentagrophytes, Trichophyton rubrum, Aspergillus niger and Candida albicans.

Bioassay-guided fractionation of the ethanol extract of the aerial parts of the Tibetan medicinal herb Clematides tangutica Skill. (Ranunculaceae), led to the isolation of two new antifungal triterpene saponins. ${ }^{113}$ Inhibitory activities of the two saponins against seven fungal strains were reported. Two new dammarane saponins were also isolated from the methanol extract of the stems of Anomospermum grandifolium Eichler (Menispermaceae). ${ }^{114}$ Activity screening of the compounds revealed antifungal properties against Candida albicans.

From the rhizomes of Dioscorea cayenensis Lam. Holl (Dioscoreaceae), new steroid saponins with antifungal activity against the human pathogenic yeasts Candida albicans, Candida glabrata and Candida tropicalis have been isolated, ${ }^{115,116}$ while three new antifungal steroidal saponins were isolated from the root of Smilax medica L. (Liliaceae). ${ }^{117}$ Examples of other antifungal saponins from medicinal plants also included those isolated from Astragalus verrucosus Moris (Leguminoseae), ${ }^{118}$ from A. auriculiformis (Fabaceae), ${ }^{119}$ and the saponins from Hedera taurica Carr. (Araliaceae) which possessed antifungal activity in vitro against Candida albicans, Candida krusei and Candida tropicalis. ${ }^{120}$

\section{Phenolic compounds}

In recent years, a large number of studies have been done on the antifungal activity of phenolic compounds of natural origin. This section deals mainly with those phenolic classes with antifungal properties found in medicinal plants, namely simple phenolic compounds, flavones and related flavonoid glycosides, coumarins and derivatives, and anthraquinones. Some of these compounds were isolated by bioassay-guided fractionation, after previously detecting antifungal activity on the part of the plant.

Antifungal activity-guided fractionation of the $n$-butanol extract of the stem bark of Artocarpus nobilis Thw (Moraceae) furnished two stilbene derivatives. ${ }^{121}$ Both compounds showed strong antifungal activity against Cladosporium cladosporioides. Four Piper species (Magnoliaceae) collected in the state of Sao Paulo, Brazil, Piper crassinervium Kunth, Piper aduncum L., Piper hostmannianum (Miquel) C. D.C. and Piper gaudichaudianum Kunth, contain the new phenolic acid derivatives crassinervic acid (Figure 9), aduncumene, hostmaniane and gaudichaudanic acid, respectively, as major secondary metabolites. ${ }^{122}$ The fungitoxic activity of these compounds was reported against Cladosporium cladosporioides and Cladosporium sphaerospermum. 


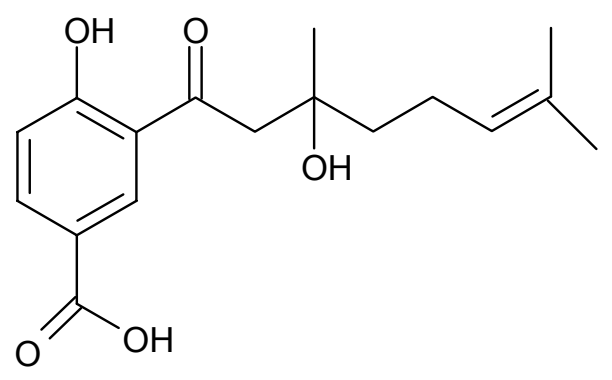

Figure 9. Structure of crassinervic acid

Three new phenolic compounds were isolated from the leaves of Baseonema acuminatum P. Choux (Asclepiadaceae). ${ }^{123}$ The compounds showed antifungal activity against two clinically isolated Candida albicans strains with $\mathrm{IC}_{50}$ values in the range of $25-100 \mu \mathrm{g} / \mathrm{ml}$. Four phenolic acid derivatives were isolated from an ethyl acetate extract of the root bark of Lycium chinense Miller (Solanaceae). ${ }^{124}$ All had antifungal effect and impeded the dimorphic transition of the pathogen Candida albicans.

Examples of other antifungal simple phenolic acid derivatives from medicinal herbs also included two phenolic compounds from Pulicaria odora L. (Asteraceae), ${ }^{125}$ those isolated from Croton hutchinsonianus Hosseus (Euphorbiaceae), ${ }^{126}$ and pinosylvin, a constituent of pine, $P$. pinaster (Pinaceae), with growth-inhibitory activity against Candida albicans and Saccharomyces cerevisiae. ${ }^{127}$

In the flavonoid group, reports on antifungal compounds from natural sources mainly concern those isolated from species of the Fabaceae and Moraceae families. Some of these flavonoids were isolated by bioassay-guided fractionation, after previously detecting antifungal activity on the part of the plant.

The crude methanol extract of Zuccagnia punctata Cav. (Fabaceae) was active against the fungal pathogens of soybean Phomopsis longicolla and Colletotrichum truncatum. ${ }^{128}$ Assayguided fractionation led to the isolation of two chalcones and one flavanone as the compounds responsible for the antifungal activity. The 95\% ethanol extract of the bark of Swartzia polyphylla D.C. (Fabaceae) possesses important antimycobacterial and antifungal activities in vitro. $^{129}$ Bioassay-guided studies performed on the crude extract afforded the flavonoids biochanin A and dihydrobiochanin A as antifungal constituents. Examples of another antifungal flavonoid from the Fabaceae family also included a novel biologically active flavonol glycoside from the ethanol extract of the stems of Teramnus labialis (L.) Spreng. ${ }^{130}$

The antifungal activity of a series of prenylated flavonoids which were purified from five different medicinal plants from the Moraceae family was evaluated by determination of $\mathrm{IC}_{50}$ using the broth microdilution method against two fungal microorganisms (Candida albicans and Saccharomyces cerevisiae). ${ }^{131}$ These results support the use of prenylated flavonoids in Asian traditional medicine to treat fungal infections. Antifungal activity-guided fractionation of the $n$ butanol extract of the leaves of $A$. nobilis (Moraceae) furnished several flavonoids which showed 
good fungicidal activity against Cladosporium cladosporioides, ${ }^{132}$ while Cudrania fruticosa (Roxburgh) Corner (Moraceae) yielded a new isoprenylated xanthone, cudrafrutixanthone, which showed antifungal activity against Candida albicans. ${ }^{133}$

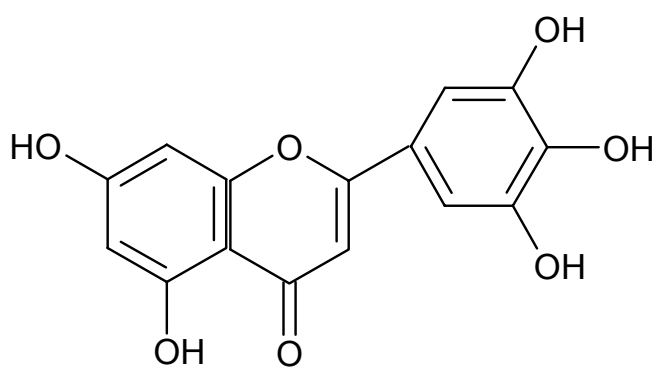

Figure 10. Structure of luteolin

Reports on the antifungal activity of flavonoids of several medicinal plants belonging to other botanical families have also been found in the literature. The leaves of Blumea balsamifera (L.) (D.C.) (Asteraceae) afforded the flavonoid luteolin (Figure 10). ${ }^{134}$ Antifungal tests indicated that luteolin had moderate activity against the fungi Aspergillus niger, Trichophyton mentagrophytes and Candida albicans. The flavonoids trifolin and hyperoside (Figure 11) isolated from Camptotheca acuminata Decne (Nyssaceae) effectively control fungal pathogens in vitro, including Alternaria alternata, Epicoccum nigrum, Pestalotia guepinii, Drechslera spp. and Fusarium avenaceum. ${ }^{135}$<smiles>COc1c(-c2ccc(O)c(O)c2)oc2cc(O)cc(O)c2c1=O</smiles>

Figure 11. Structure of hyperoside

Examples of other antifungal flavonoids from medicinal species also included those isolated from the stem bark of Erythrina burtii Ball. (Leguminoseae), ${ }^{136}$ and the main flavonoid 4'-methoxy-5,7-dihydroxyflavone 6-C-glucoside (isocytisoside) from the leaves and stems of Aquilegia vulgaris L. (Ranunculaceae), which showed activity against the mould Aspergillus niger. ${ }^{137}$

In addition to simple phenolic derivatives and flavonoids, studies into other antifungal phenolic compounds from natural sources also included coumarins and anthraquinones. Some of 
these compounds were isolated by bioassay-guided fractionation, after previously detecting antifungal activity on the part of the plant.

In the continuous search for antifungal compounds from plants, the hydroxycoumarin scopoletin (Figure 12) was isolated from seed kernels of Melia azedarach L. (Meliaceae). ${ }^{138}$ Guided-fractionation using Fusarium verticillioides as test organisms led to the isolation of scopoletin, which had a $\mathrm{IC}_{50}$ value of $1.5 \mathrm{mg} / \mathrm{ml}$ in the microbroth dilution method. The methanol extract of the aerial parts of the shrub Mutisia friesiana Cabrera (Asteraceae) afforded two new 5-methylcoumarins, mutisicoumarones C and D. ${ }^{139}$ The compounds showed antifungal effect against the phytopathogenic fungus Cladosporium cucumerinum.

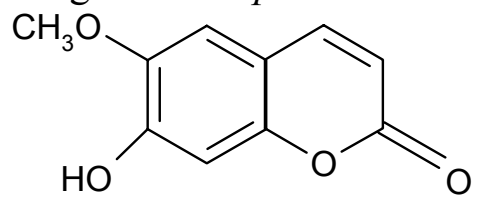

Figure 12. Structure of scopoletin

Tithoniamarin is a new isocoumarin dimer isolated from Tithonia diversifolia (Hemsl) Gray (Asteraceae). ${ }^{140}$ Preliminary studies showed that tithoniamarin has antifungal and herbicidal activities against Microbotryum violaceum and Chlorella fusca. Deng and Nicholson $^{141}$ reported the antifungal properties of surangin B, a coumarin from Mammea longifolia (Wight ex Wall.) Planch. \& Triana (Guttiferae). As an inhibitor of mycelial growth, surangin $\mathrm{B}$ showed the strongest activity against Rhizoctonia solani $\left(\mathrm{IC}_{50}\right.$ of $3,8 \mu \mathrm{M}$ ) and Botrytis cinerea $\left(\mathrm{IC}_{50}\right.$ of $\left.11.2 \mu \mathrm{M}\right)$. Inhibitory effects was less pronounced in Alternaria dauci and Fusarium oxysporum ( $\mathrm{IC}_{50}$ values $>$ of $30 \mu \mathrm{M}$ ) and absent in Trichoderma harzianum.

In the anthraquinone group, there are only a few reports concerning their antifungal activity. Manojlovic et al. ${ }^{142}$ reported the antifungal activity of the methanol extracts and the major anthraquinone aglycones, alizarin and emodin (Figure 13), of Rubia tinctorum L. (Rubiaceae) and Rhamnus frangula L. (Rhamnaceae).<smiles>Cc1cc(O)c2c(c1)C(=O)c1cc(O)cc(O)c1C2=O</smiles>

Figure 13. Structure of emodin

The fungicidal activities of Cassia tora L. (Leguminoseae) and its active principles were determined against Botrytis cinerea, Erysiphe graminis, Phytophora infestans, Puccinia recondita, Pyricularia grisea and Rhizoctonia solani. ${ }^{143}$ Emodin (Figure 13), physcion and rhein 
(Figure 14) were isolated from the chloroform extract and showed strong fungicidal activity against the microorganisms tested. Furthermore, aloe-emodin showed strong and moderate fungicidal activity against Botrytis cinerea and Phytophthora infestans, respectively. Examples of other antifungal anthraquinones from medicinal species also included a new 1,3-dihydroxy-2methyl-5,6-dimethoxyanthraquinone from the roots of Prismatomeris fragrans Wall (Rubiaceae). ${ }^{144}$<smiles>O=C(O)c1cc(O)c2c(c1)C(=O)c1cccc(O)c1C2=O</smiles>

Figure 14. Structure of rhein

\section{Alkaloids}

Reports of antifungal alkaloids from medicinal species have also been found in the literature. Some of these plants have been reported to be used in folk medicine as anti-infectious agents.<smiles></smiles>

Figure 15. Structure of berberine

Bioassay-guided fractionation of the hexane/ethyl acetate/water crude extract of the aerial parts of Haplophyllum sieversii Lincz et Wed. (Rutaceae) was performed after preliminary screening data indicated the presence of growth-inhibitory compounds against Colletotrichum fragariae, Colletotrichum gloeosporioides and Colletotrichum acutatum. ${ }^{145}$ Fractionation resulted in the isolation of the bioactive alkaloids, flindersine, anhydroevoxine and haplamine. Of them, flindersine and haplamine demonstrated the highest level of antifungal activity. The crude extract of Mahonia aquifolium (Pursh) Nutt. (Berberidaceae) stem bark and its two main 
protoberberine alkaloids, berberine (Figure 15) and jatorrhizine, were tested for their in vitro antifungal activity. ${ }^{146}$ Twenty strains of Candida spp. isolated from chronic vulvovaginal candidoses were tested for their susceptibility to crude extracts and two isolated alkaloids. The results indicate a rational basis for the traditional use of $M$. aquifolium for localised skin and mucosal infection therapy, as well as for the possible development of a preparation for supportive therapy of these diseases.

A novel alkaloid, 2-(3,4-dimethyl-2,5-dihydro-1H-pyrrol-2-yl)-1-methylethyl pentanoate was isolated from the plant Datura metel L. (Solanaceae). ${ }^{147}$ The in vitro activity of this dihydropyrrole derivative against Aspergillus and Candida species was evaluated. The compound was found to be active against all the species tested, namely Candida albicans, Candida tropicalis, Aspergillus fumigatus, Aspergillus flavus and Aspergillus niger. Activityguided fractionation of an Aniba panurensis (Meissn) Mez (Lauraceae) organic extract has led to the isolation of the novel alkaloid, 6,8-didec-(1Z)-enyl-5,7-dimethyl-2,3-dihydro-1Hindolizinium. ${ }^{148}$ Bioassays performed in vitro demonstrated the toxicity of this alkaloid to a drugresistant strain of Candida albicans.

Examples of other antifungal alkaloids from medicinal species also included a $\beta$-carboline, a tryptamine- and two phenylethylamine-derived alkaloids from the aerial parts and roots of Cyathobasis fruticulosa (Bunge) Aellen (Chenopodiaceae), ${ }^{149}$ and haloxylines A and B, new piperidine alkaloids from the chloroform extract of Haloxylon salicornium L. (Chenopodiaceae), which displayed antifungal potentials. ${ }^{150}$

\section{Peptides and proteins}

In the last years, reports on the antifungal activity of peptides and proteins isolated from medicinal plants have mainly concerned species of the Fabaceae family. From the seeds of haricot beans, Phaseolus vulgaris L. (Fabaceae), Wong and $\mathrm{Ng}^{151}$ purified an antifungal peptide. This peptide, named vulgarinin, displayed antifungal activity toward fungal species such as Fusarium oxysporum, Mycosphaerella arachidicola, Physalospora piricola and Botrytis cinerea. From another Phaseolus species, mung bean (Phaseolus mungo L.) seeds, a chitinase with antifungal activity was isolated. ${ }^{152}$ This protein exerted antifungal action toward Fusarium solani, Fusarium oxysporum, Mycosphaerella arachidicola, Pythium aphanidermatum and Sclerotium rolfsii. This species also yielded a novel lysozyme exhibiting antifungal activity toward Botrytis cinerea. ${ }^{153}$ Another Fabaceae species, Trigonella foenum-graecum L., yielded defensins, small cysteine rich peptides, which exhibited antifungal activity against the broad host range fungus Rhizoctonia solani and the peanut leaf spot fungus Phaeoisariopsis personata. ${ }^{154}$

Reports on the antifungal activity of peptides and proteins isolated from medicinal plants belonging to other botanical families have also been found in the literature. An antifungal protein, AFP-J, was purified from potato tubers, Solanum tuberosum cv L. Jopung (Solanaceae). ${ }^{155}$ AFP-J strongly inhibited yeast fungal strains, including Candida albicans, 
Trichosporon beigelii and Saccharomyces cerevisiae, whereas it exhibited no activity against crop fungal pathogens. Taira et al. ${ }^{156}$ purified three proteins, designated pineapple leaf chitinaseA, -B and -C, from the leaves of pineapple, Ananas comosus L. (Bromeliaceae). Pineapple leaf chitinase-B exhibits strong antifungal activity toward Trichoderma virida, but the others do not.

Another chitinase with antifungal activity was also purified from the bulbs of the plant Urginea indica L. (Liliaceae), known as Indian squill. ${ }^{157}$ The protein was an active growth inhibitor of the fungal pathogens Fusarium oxysporum and Rhizoctonia solani in an in vitro assay. A novel protein was isolated from the Chinese herb Astragalus mongholicus Bunge (Leguminoseae). ${ }^{158}$ It exerted antifungal activity against Botrytis cinerea, Fusarium oxysporum, Colletotrichum spp. and Drechslera turcia, but not against Rhizoctonia solani and Mycosphaerella arachidicola.

Examples of other antifungal peptides and proteins from medicinal species also included two chitin-binding proteins from spindle tree Evonymus europaeus L. (Celastraceae), ${ }^{159}$ a thaumatin-like protein from banana Musa acuminata Colla (Musaceae), ${ }^{160}$ and a protein from ginger rhizomes Zingiber officinalis L. (Zingiberaceae), which exerted antifungal activity toward various fungi, including Botrytis cinerea, Fusarium oxysporum, Mycosphaerella arachidicola and Physalospora piricola. ${ }^{161}$

\section{Acknowledgements}

The technical assistance of Ms. P. Brooke-Turner is gratefully acknowledged.

\section{References}

1. Bergeron, C.; Marston, A.; Gauthier, R.; Hostettmann, K. Int. J. Pharmacog. 1996, 34, 233.

2. Meckes, M.; Villasreal, M. L.; Tortoriello, J.; Berlin, B.; Berlin, E. A. Phytother. Res. 1995, 9, 244.

3. Verastegui, M. A.; Sanchez, C. A.; Heredia, N. L.; Garcia-Alvarado, J. S. J. Ethnopharmacol. 1996, 52, 175.

4. Schmourlo, G.; Mendonca, R. R.; Alviano, C. S.; Costa, S. S. J. Ethnopharmacol. 2005, 96, 563.

5. Duarte, M. C.; Figueira, G. M.; Sartoratto, A.; Rehder, V. L.; Delarmelina, C. J. Ethnopharmacol. 2005, 97, 305.

6. Muschietti, L.; Derita, M.; Sulsen, V.; De Dios, J.; Ferrero, G.; Zacchino, S.; Martino, V. J. Ethnopharmacol. 2005, 102, 233.

7. Turchetti, B.; Pinelli, P.; Buzzini, P.; Romani, A.; Heimler, D.; Franconi, F.; Martini, A. Phytother. Res. 2005, 19, 44.

8. Tadeg, H.; Mohammed, E.; Asres, K.; Gebre, T. J. Ethnopharmacol. 2005, 100, 168. 
9. Lamidi, M.; Digiorgio, C.; Delmas, F.; Favel, A.; Egele, C.; Rondi, M. L.; Ollivier, E.; Uze, L.; Balansard, G. J. Ethnopharmacol. 2005, 102, 185.

10. De Boer, H. J.; Kool, A.; Broberg, A.; Mzirov, W. R.; Hedberg, I.; Levenfors, J. J. J. Ethnopharmacol. 2005, 96, 461.

11. Zaidi, M. A.; Crow, S. A., Jr. J. Ethnopharmacol. 2005, 96, 331.

12. Phongpaichit, S.; Subhadhirasakul, S.; Wattanapiromsakul, C. Mycoses 2005, 48, 333.

13. Buwa, L. V.; Van Staden, J. J. Ethnopharmacol. 2006, 103, 139.

14. Mothana, R. A.; Lindequist, V. J. Ethnopharmacol. 2005, 96, 177.

15. Hymete, A.; Iversen, T. H.; Rohloff, J.; Erko, B. Phytomedicine 2005, 12, 675.

16. Stein, A. C.; Sortino, M.; Avancini, C.; Zacchino, S.; Von Poser, G. J. Ethnopharmacol. 2005, 99, 211.

17. Mares, D.; Romagnoli, C.; Tosi, B.; Andreotti, E.; Chillemi, G.; Poli, F. Mycopathologia 2005, 160, 85.

18. Loizzo, M. R.; Statti, G. A.; Tundis, R.; Conforti, F.; Bonesi, M.; Autelitano, G.; Houghton, P. J.; Miljkovic, A.; Menichini, F. Phytother. Res. 2004, 18, 777.

19. Zhu, X. F.; Zhang, H. X.; Lo, R. Fitoterapia 2005, 76, 108.

20. Queiroz, E. F.; Ioset, J. R.; Ndjoko, K.; Guntern, A.; Foggin, C. M.; Hostettmann, K. Phytochem. Anal. 2005, 16, 166.

21. Rai, M. K.; Varma, A.; Pandev, A. K. Mycoses 2004, 47, 479.

22. Shams, M.; Shokoohamiri, M. R.; Amirrajab, N.; Moghadasi, B.; Ghajari, A.; Zeini, F.; Sadeghi, G. Fitoterapia 2006, 77, 321.

23. Ghahfarakhi, M. S.; Goodarzi, M.; Abvaneh, M. R.; Al Tiraihi, T.; Sevedipovr, G. Fitoterapia 2004, 75, 645.

24. Iwalokun, B. A.; Ogunledun, A.; Ogbolu, D. O.; Bamiro, S. B.; Jimi, J. J. Med. Food 2004, 7, 327.

25. Amin, M.; Kapadnis, B. P. Indian J. Exp. Biol. 2005, 43, 751.

26. Mihara, R.; Barry, K. M.; Mohammed, C. L.; Mitsunaga, T. J. Chem. Ecol. 2005, 31, 789.

27. Deepa, M. A.; Narmatha, V.; Basker, S. Fitoterapia 2004, 75, 581.

28. Cvetnic, Z.; Vladimir, S. Acta Pharm. 2004, 54, 243.

29. Bafi, N. F.; Arnason, J. T.; Baker, J.; Smith, M. L. Phytomedicine 2005, 12, 370.

30. Taguchi, Y.; Ishibashi, H.; Takizawa, T.; Inoue, S.; Yamaguchi, H.; Abe, S. Nippon Ishiukin Gakkai Zasshi 2005, 46, 27.

31. Takahashi, T.; Kokubo, R.; Sakaino, M. Lett. Appl. Microbiol. 2004, 39, 60.

32. Silva, M. R.; Oliveira, J. G., Jr.; Fernández, O. F.; Passos, X. S.; Costa, C. R.; Souza, L. K.; Lemos, J. A.; Paula, J. R. Mycoses 2005, 48, 172.

33. Lemos, J. A.; Passos, X. S.; Fernandes, O. F.; Paula, J. R.; Ferri, P. H.; Souza, L. K.; Lemos, A. A.; Silva, M. R. Mem. Inst. Oswaldo Cruz 2005, 100, 55.

34. Amanlov, M.; Fazeli, M. R.; Arvin, A.; Amin, H. G.; Farsam, H. Fitoterapia 2004, 75, 768.

35. Masoko, P.; Picard, J.; Eloff, J. N. J. Ethnopharmacol. 2005, 99, 301. 
36. Batawila, K.; Kokov, K.; Koumaglo, K.; Gbeassor, M.; De Foucalt, B.; Bouchet, P.; Akpagana, K. Fitoterapia 2005, 76, 264.

37. Khattak, S.; Saeed, P.; Ullah, H.; Ahmad, W.; Ahmad, M. Fitoterapia 2005, 76, 254.

38. Wilson, B.; Abraham, G.; Manju, V. S.; Mathew, M.; Vimala, B.; Sundaresan, S.; Nambisan, B. J. Ethnopharmacol. 2005, 99, 147.

39. Nidiri, E. S.; Babu, C.S. Phytother. Res. 2005, 19, 447.

40. Unver, N.; Irem, G.; Tansel, H. Fitoterapia 2005, 76, 226.

41. Gurgel, L. A.; Sidrim, J. J.; Martins, D. T.; Cechinel, V.; Rao, V. S. J. Ethnopharmacol. 2005, 97, 409.

42. Agrawal, A.; Srivastava, S.; Srivastava, J. N.; Srivasava, M. M. Biomed. Environ Sci. 2004, 17, 359.

43. Torras, M. A.; Faura, C. A.; Schonlau, F.; Rohdewald, P. Phytother. Res. 2005, 19, 647.

44. Lahlou, M.; El Mahi, M.; Hamamouchi, J. Ann. Pharm. Fr. 2002, 60, 410.

45. De Campos, M. P.; Cechinel, V.; Da Silva, R. Z.; Yunes, R. A.; Zacchino, S.; Juarez, S.; Bella, R. C.; Bella, A. Biol. Pharm. Bull. 2005, 28, 1527.

46. Aljabre, S. H.; Randhawa, M. A.; Akhtar, N.; Alakloby, O. M.; Alqurashi, A. M.; Aldossary, A. J. Ethnopharmacol. 2005, 101, 116.

47. Favel, A.; Kemertelidze, F.; Benidze, M.; Fallague, K.; Regli, P. Phytother. Res. 2005, 19, 158.

48. Agrawal, A.; Srivastava, S.; Srivastava, M. N. Hindustan Antibiot. Bull. 2003, 45, 1.

49. Agrawal, A.; Srivastava, S.; Srivastava, J. N.; Srivastava, M. M. J. Environ. Biol. 2004, 25, 307.

50. Fenner, R.; Sortino, M.; Rates, S. M.; Dall'Agnol, R.; Ferraz, A.; Bernardi, A. P.; Albring, D.; Nor, C.; Van Poser, G.; Schapoval, E.; Zacchino, S. Phytomedicine 2005, 12, 236.

51. Rojas, R.; Doroteo, V.; Bustamante, B.; Baver, J.; Lock, O. Fitoterapia 2004, 75, 754.

52. Ahmadu, A.; Haruno, A. K.; Garba, M.; Ehinmida, J. Q.; Sarker, S. D. Fitoterapia 2004, 75, 729.

53. Wordeamauvel, Y.; Abate, G.; Chryssanthon, E. Ethip. Med. J. 2005, 43, 31.

54. Meepagala, K. M.; Sturtz, G.; Wedge, D. E.; Schroder, K. K.; Duke, S. Q. J. Chem. Ecol. 2005, 31, 1567.

55. Kumar, R. S.; Sivakumar, T.; Sunderam, R. S.; Gupta, M.; Mazumdar, N. K.; Gomathi, P.; Rajeshwar, Y.; Saravanan, S.; Kumar, M. S.; Murugesh, K.; Kumar, K. A. Braz. J. Med. Biol. Res. 2005, 38, 1015.

56. Taira, T.; Ohdomari, A.; Nakama, N.; Shimoji, M.; Ishihara, M. Biosci. Biotechnol. Biochem. 2005, 69, 811.

57. Quiroga, E. N.; Samprieto, A. R.; Vattuone, M. A. Lett. Appl. Microbiol. 2004, 39, 7.

58. Tarfa, F. D.; Obodozic, O. O.; Mshelin, E.; Ibrahim, K.; Temple, V. J. Indian J. Exp. Biol. 2004, 42, 326.

59. Giordani, R.; Regli, P.; Kaloustian, J.; Mikail, C.; Abou, L.; Portugal, H. Phytother. Res. 2004, 18, 990. 
60. D’Auria, F. D.; Tecca, M.; Strippoli, V.; Salvatore, G.; Battinelli, L.; Mazzanti, G. Med. Mycol. 2005, 43, 391.

61. Angioni, A.; Barra, A.; Coronco, V.; Dessi, S.; Cabras, P. J. Agric. Food Chem. 2006, 54, 4364.

62. Angioni, A.; Barra, A.; Cereti, E.; Barile, D.; Coisson, J. D.; Arlorio, M.; Dessi, S. ; Coroneo, V.; Cabras, P. J. Agric. Food Chem. 2004, 52, 3530.

63. Nakamura, C. V.; Ishida, K.; Faccin, L. C.; Filho, B. P.; Cortez, D. A.; Rozental, S.; De Souza, W.; Ueda, T. Res. Microbiol. 2004, 155, 579.

64. Sachetti, G.; Medici, A.; Maietti, S.; Radice, M.; Muzzoli, M.; Manfredini, S.; Braccioli, E.; Bruni, R. J. Agric. Food Chem. 2004, 52, 3486.

65. Sonboli, A.; Salehi, P.; Yousefzadi, M. Z. Naturforsch. 2004, 59, 653.

66. Salgueiro, L. R.; Piato, E.; Goncalves, M. J.; Pina, C.; Cavaleiro, C.; Rodrigues, A. G.; Palmeira, A.; Tavares, C.; Costa, S.; Martinez, J. Planta Med. 2004, 70, 572.

67. Alvarez, P. P.; Bishop, C. D.; Pascual, M. J. Phytochemistry 2001, 57, 99.

68. Kordali, S.; Cakir, A.; Mavi, A.; Kilic, H.; Yildirim, A. J. Agric. Food Chem. 2005, 53, 1408 .

69. Govinden, J.; Magan, N.; Gurib, A.; Gauvin, A.; Smadja, J.; Kodja, H. Biol. Pharm. Bull. 2004, 27, 1814.

70. Romagnoli, C.; Bruni, R.; Andreotti, E.; Rai, M. K.; Vicentini, C. B.; Mares, D. Protoplasma 2005, 225, 57.

71. Cardenas, N. C.; Zavala, M. A.; Aguirre, J. R.; Perez, C.; Perez, S. J. Agric. Food Chem. 2005, 53, 4347.

72. Tundis, R.; Statti, G. A.; Conforti, F.; Bianchi, A.; Agrimonti, C.; Sachetti, G.; Muzzoli, M.; Ballero, M.; Menichini, F.; Poli, F. Nat. Prod. Res. 2005, 19, 379.

73. Portillo, M. C.; Viramontes, S.; Muñoz, L. N.; Gastelum, M. G.; Nevarez, G. V. J. Food Prot. 2005, 68, 2713.

74. Viljoen, A. M.; Subramoney, S.; Van Vuuren, S. F.; Baser, K. H.; Demirci, B. J. Ethnopharmacol. 2005, 96, 271.

75. Lopez, A. G.; Theumer, M. G.; Zygadlo, J. A.; Rubinstein, H. R. Mycopathologica 2004, 58, 343.

76. Sharma, N.; Tripathi, A. World J. Microbiol. Biotechnol. 2006, 22, 587.

77. Al Burtamani, S. K.; Fatope, M. O.; Marwah, R. G.; Onifade, A.K.; Al Saidi, S.H. J. Ethnopharmacol. 2005, 96, 107.

78. Simic, A.; Sokovic, M.D.; Ristic, M.; Grujic, S.; Vukojevic, J.; Marin, P.D. Phytother. Res. 2004, 18, 713.

79. Wang, S. Y.; Chen, P. F.; Chang, S. T. Bioresour. Technol. 2005, 96, 813.

80. Cheng, S. S.; Wu, C. L.; Chang, H. T.; Kao, Y. T.; Chang, S. T. J. Chem. Ecol. 2004, 30, 1957.

81. Hong, E. J.; Na, K. J.; Choi, I. G.; Choi, K. C.; Jeung, E. B. Biol. Pharm. Bull. 2004, 27, 863. 
82. Cavaleiro, C.; Pinto, E.; Goncalves, M. J.; Salgueiro, L. J. Appl. Microbiol. 2006, 100, 1333.

83. Pyun, M. S.; Shin, S. Phytomedicine 2006, 13, 394.

84. Singh, G.; Maurva, S.; Catalan, C.; De Lampasona, M. P. J. Agric. Food Chem. 2004, 52, 3292.

85. Cheng, S. S.; Lin, H. Y.; Chang, S. T. J. Agric. Food Chem. 2005, 53, 614.

86. Maksimovic, Z. A.; Dordevic, S.; Mraovic, M. Fitoterapia 2005, 76, 112.

87. Zhang, Z. Z.; Li, Y. B.; Qi, L.; Wan, X. C. J. Agric. Food Chem. 2006, 54, 3936.

88. Alviano, W. S.; Mendinca, R. R.; Alviano, D. S.; Bizzo, H. R.; Souto, T.; Rodrigues, M. L.; Bolognese, A. M.; Alviano, C. S.; Souza, M. M. Oral Microbiol. Immunol. 2005, 20, 101.

89. Shin, S.; Lim, S. J. Appl. Microbiol. 2004, 97, 1289.

90. Fernandez, A. M.; Gomez, M. V.; Velasco, A.; Camacho, A. M.; Fernandez, C.; Altarejos, J. J. Agric. Food Chem. 2004, 52, 6414.

91. Ahmed, A. A.; Bishr, M. M.; El Shanawany, M. A.; Attia, E. Z.; Ross, S. A.; Pare, P. W. Phytochemistry 2005, 66, 1680.

92. Jasicka, I.; Lipok, J.; Nowakowska, E. M.; Wieczorek, P. P.; Mylnarz, P.; Kafarsli, P. Z. Naturforsch. 2004, 59, 791.

93. Portillo, A.; Vila, R.; Freixa, B.; Ferro, E.; Parello, T.; Casanova, J.; Cañigeral, S. J. Ethnopharmacol. 2005, 97, 49.

94. Scher, J. M.; Speakman, J. B.; Zapp, J.; Becker, H. Phytochemistry 2004, 65, 2583.

95. Fujita, K.; Kubo, I. J. Agric. Food Chem. 2005, 53, 5187.

96. Barrero, A. F.; Quilez, J. F.; Lara, A.; Herrador, M. M. Planta Med. 2005, 71, 67.

97. Yokose, T.; Katamoto, K.; Park, S.; Matsuura, H.; Yoshihara, T. Biosci. Biotechnol. Biochem. 2004, 68, 2640.

98. Barrero, A. F.; Oltra, J. E.; Alvarez, M.; Raslan, D. S.; Saude, D. A.; Akssira, M. Fitoterapia 2000, 71, 60.

99. Skaltsa, H.; Lazari, D.; Panagouleas, C.; Georgiadov, E.; Garcia, B.; Sokovic, M. Phytochemistry 2000, 55, 903.

100.Meng, J. C.; Hu, Y. F.; Chen, J. H.; Tan, R. X. Phytochemistry 2001, 58, 1141.

101.Lavault, M.; Landreau, A.; Larcher, G.; Bouchara, J. P.; Pagniez, F.; Le Pape, P.; Richomme, P. Fitoterapia 2005, 76, 363.

102.Cavin, A. L.; Hay, A. E.; Marston, A.; Stoeckli, H.; Scopelliti, R.; Diallo, D.; Hostettmann, K. J. Nat. Prod. 2006, 69, 768.

103. Marthanda, M.; Subramanyan, M.; Hima, M.; Annapurna, J. Fitoterapia 2005, 76, 336.

104.Adou, E.; Williams, R. B.; Schilling, J. K.; Malone, S.; Meyer, J.; Wisse, J. H.; Frederik, D.; Koere, D.; Werkhoven, M. C.; Snipes, C. E.; Werk, T. L.; Kingston, D. G. Bioorg. Med. Chem. 2005, 13, 6009.

105. Thongnest, S.; Mahidol, C.; Sutthivaivakit, S.; Ruchirawat, S. J. Nat. Prod. 2005, 68, 1632.

106.Abdelgaleil, S. A.; Hashinaga, F.; Nakatani, M. Pest Manag. Sci. 2005, 61, 186.

107.Becker, H.; Scher, J. M.; Speakman, J. B.; Zapp, J. Fitoterapia 2005, 76, 580.

108.Luo, D. Q.; Wang, H.; Tian, X.; Shao, N. J.; Liu, J. K. Pest Manag. Sci. 2005, 61, 85. 
109.Tostao, Z.; Nonoha, J. P.; Cabrita, E. J.; Medeiros, J.; Justino, J.; Bermejo, J.; Rauter, A. P. Fitoterapia 2005, 76, 173.

110.Renault, S.; De Lucca, A. J.; Bove, S.; Bland, J. M.; Vigo, C. B.; Selitremikoff, C. P. Med. Mycol. 2003, 4, 75.

111.Gonzalez, M.; Zamilpa, A.; Marquina, S.; Navarro, V.; Alvarez, L. J. Nat. Prod. 2004, 67, 938.

112.Zamilpa, A.; Tortoriello, J.; Navarro, V.; Delgado, G.; Alvarez, L. J. Nat. Prod. 2002, 65, 1815.

113.Du, Z.; Zhu, N.; Ze, N.; Shen, Y. Planta Med. 2003, 69, 547.

114.Plaza, A.; Cinco, M.; Tubaro, A.; Pizza, C.; Piacente, S. J. Nat. Prod. 2003, 66, 1606.

115.Sauton, M.; Mitaine, A. C.; Miyamoto, T.; Dongmo, A.; Lacaille, M. A. Planta Med. 2004, 70, 90.

116.Sauton, M.; Mitaine, A. C.; Miyamoto, T.; Dongmo, A.; Lacaille, M. A. Chem. Pharm. Bull. 2004, 52, 1353.

117.Sauton, M.; Miyamoto, T.; Lacaille, M. A. J. Nat. Prod. 2005, 68, 1489.

118.Pistelli, L.; Bertoli, A.; Lepori, E.; Morelli, I.; Panizzi, L. Fitoterapia 2002, 73, 336.

119.Mandal, P.; Sinha, S. P.; Mandal, N. C. Fitoterapia 2005, 76, 462.

120.Mel'nichenko, E. G.; Kirsanova, M. A.; Grishkovets, V. I.; Tysh, L. V.; Krivorutchenko, I. L. Mikrobiol. Z. 2003, 65, 8.

121.Javasinghe, V. L.; Puvanendran, S.; Hara, N.; Fujimoto, Y. Nat. Prod. Res. 2004, 18, 571.

122.Lago, J. H.; Ramos, C. S.; Casanova, D. C.; Morandim, A. A.; Bergamo, D. C.; Cavalheiro, A. J.; Bolzani, V. S.; Furlan, M.; Guimaraes, E. F.; Young, M. C.; Kato, M. J. J. Nat. Prod. 2004, 67, 783.

123.De Leo, M.; Braca, A.; De Tomasi, N.; Norscia, I.; Morelli, I.; Battinelli, L.; Mazzanti, G. Planta Med. 2004, 70, 841.

124.Lee, D. G.; Park, Y.; Kim, M. R.; Jung, H. J.; Seu, Y. B.; Hahm, K. S.; Woo, E. R. Biotechnol. Lett. 2004, 26, 1125.

125.Ezoubeiri, A.; Gadhi, C. A.; Edil, N.; Benharref, A.; Jana, M.; Vanhaelen, M. J. Ethnopharmacol. 2005, 99, 287.

126. Athikomkulchal, S.; Prawat, H.; Thasana, N.; Ruangrungsi, N.; Ruchirawat, S. Chem. Pharm. Bull. 2006, 54, 262.

127.Lee, S. K.; Lee, H. J.; Min, H. Y.; Park, E. J.; Lee, K. M.; Ahn, Y. H.; Cho, Y. J.; Pyee, J. H. Fitoterapia 2005, 76, 258.

128.Svetaz, L.; Tapia, A.; Lopez, S. N.; Furlan, R. L.; Petenatti, E.; Pioli, R.; Schmeda, G.; Zacchino, S. A. J. Agric. Food Chem. 2004, 52, 3297.

129.Rojas, R.; Bustamante, B.; Ventosilla, P.; Fernandez, I.; Caviedes, L.; Gilman, R. M.; Lock, O.; Hammond, G. B. Chem. Pharm. Bull. 2006, 54, 278.

130. Yadava, R. N.; Jain, S. Nat. Prod. Res. 2004, 18, 537.

131.Sohn, H. Y.; Son, K. H.; Kwon, C. S.; Kwon, G. S.; Kang, S. S. Phytomedicine 2004, 11, 666. 
132.Jayasinghe, L.; Balasooriva, B. A.; Padmini, W. C.; Hara, N.; Fujimoto, Y. Phytochemistry 2004, 65, 1287.

133.Wang, Y. H.; Hou, A. J.; Zhu, G. F.; Chen, D. F.; Sun, H. D. Planta Med. 2005, 71, 273.

134.Ragasa, C. Y.; Co, A. L.; Rideout, J. A. Nat. Prod. Res. 2005, 19, 231.

135.Li, S.; Zhang, Z.; Cain, A.; Wang, B.; Long, M.; Taylor, J. J. Agric. Food Chem. 2005, 53, 32.

136. Yenesew, A.; Derese, S.; Midiwo, J. O.; Bii, C. C.; Heydenreich, M.; Peter, M. G. Fitoterapia 2005, 76, 469.

137.Bylka, W.; Szaufer, M.; Matlawska, J.; Goslinska, O. Lett. Appl. Microbiol. 2004, 39 , 93.

138. Carpinella, M. C.; Ferravoli, C. G.; Palacios, S. M. J. Agric. Food Chem. 2005, 53, 2922.

139. Viturro, C. F.; De la Fuente, J. R.; Maier, M. S. J. Nat. Prod. 2004, 67, 778.

140.Yemele, M.; Krohn, K.; Hussain, H.; Dongo, E.; Schulz, B.; Hu, Q. Nat. Prod. Res. 2006, $20,842$.

141.Deng, Y.; Nicholson, R. A. Planta Med. 2005, 71, 364.

142. Manojlovic, N. T.; Solujic, S.; Sukdolak, S.; Milosev, M. Fitoterapia 2005, 76, 244.

143.Kim, Y. M.; Lee, C. H.; Kim, H. G.; Lee, H. S. J. Agric. Food. Chem. 2004, 52, 6096.

144.Kanokmedhakul, K.; Kanokmedhakul, S.; Phatchana, R. J. Ethnopharmacol. 2005, 100, 284.

145.Cantrell, C. L.; Schrader, K. K.; Mamonov, L. K.; Sitpaeva, G. T.; Kustova, T. S.; Dunbar, C.; Wedge, D. E. J. Agric. Food Chem. 2005, 53, 7741.

146.Slobodnikova, L.; Kost'alova, D.; Labudova, D.; Kotulova, D.; Kettmann, V. Phytother. Res. 2004, 18, 674.

147.Dabur, R.; Chhillar, A. K.; Yadav, V.; Kamal, P. K.; Gupta, J.; Sharma, G. L. J. Med. Microbiol. 2005, 54, 549.

148.Klausmeyer, P.; Chmurny, G. N.; McCloud, T. G.; Tucker, K. D.; Schoemaker, R. H. J. Nat. Prod. 2004, 67, 1732.

149.Bahceeuli, A. K.; Kurnan, S.; Kolak, U.; Topcu, G.; Adou, E.; Kingston, D. G. J. Nat. Prod. 2005, 68, 956.

150.Ferheen, S.; Ahmed, E.; Afza, N.; Malik, A.; Shah, M. R.; Nawaz, S. A.; Choudhary, M. I. Chem. Pharm. Bull. 2005, 53, 570.

151.Wong, J. H.; Ng, T. B. Int. J. Biochem. Cell Biol. 2005, 37, 1626.

152.Wang, S.; Wu, J.; Rao, P.; Ng, T. B.; Ye, X. Protein Expr. Purif. 2005, 40, 230.

153.Wang, S.; Ng, T. B.; Chen, T.; Lin, D.; Wu, J.; Rao, P.; Ye, X. Biochem. Biophys. Res. Commun. 2005, 327, 820 .

154.Olli, S.; Kirti, P. B. J. Biochem. Mol. Biol. 2006, 39, 278.

155.Park, Y.; Choi, B. H.; Kwak, J. S.; Kang, C. W.; Lim, H. T.; Cheong, H. S.; Hahm, K. S. J. Agric. Food Chem. 2005, 53, 6491.

156.Taira, T.; Toma, N.; Ishihara, M. Biosci. Biotechnol. Biochem. 2005, 69, 189.

157. Shenoy, S. R.; Kameshwari, M. N.; Swaminathan, S.; Gupta, M. N. Biotechnol. Prog. 2006, 22,631 . 
158. Yan, Q.; Jiang, Z.; Yang, S.; Deng, W.; Han, L. Arch. Biochem. Biophys. 2005, 442, 72.

159. Vanden Bergh, K. P.; Rouge, P.; Proast, P.; Coosemans, J.; Krouglova, T.; Engelborghs, Y.; Peumans, W. J.; Van Damme, E. J. Planta 2004, 219, 221.

160.Leone, P.; Menu, L.; Peumans, W. J.; Pavan, F.; Barre, A.; Roussel, A.; Van Damme, E. J.; Rouge, P. Biochimie 2006, 88, 45.

161.Wang, H.; Ng, T. B. Biochem. Biophys. Res. Commun. 2005, 336, 100. 